\title{
Effectiveness of Problem Solving Learning Model towards Student Learning Outcomes on Acid-Base Solution in SMA Negeri 1 Buko on Academic Year 2018-2019
}

\section{*Yulianti Siako \& Kasmudin Mustapa}

Pendidikan Kimia/FKIP - Universitas Tadulako, Palu - Indonesia 94119

Received 19 June 2020, Revised 17 July 2020, Accepted 12 August 2020

doi: $10.22487 / \mathrm{j} 24775185.2020 . v 9 . i 3 . p p 162-167$

\begin{abstract}
This study aimed to determine the effectiveness of problem-solving learning models on students' learning outcomes in the acid-base solutions topic in SMA Negeri 1 Buko on Academic Year 2018-2019. This type of research was a true experiment with a non-randomized posttest two group design. The population of this research was all students of class XI MIA, the sampling techniques was saturated sampling methods. The sample used was students of class XI MIA 1 and XI MIA 2 as experimental class 1 and experimental class 2. The testing of students' learning outcomes data was using one-party statistical analysis t-test to test the completeness of individual learning outcomes and classical completeness test to test the overall percentage of mastery learning. The results of data analysis obtained, the mean experimental class 1 (X1) was 75.5 with a standard deviation of 10.71 and the average experimental class 2 (X2) was 76.43 with a standard deviation of 12.77 . The results of hypothesis testing with one-party t-test statistics in the experimental class 1 and 2 was obtained $t_{\text {count }}>$ $t_{\text {table }}(2.321>1.740 ; 2.306>2.101)$ with a significance level of $\alpha=0.05$ and degrees of freedom 18 and 19 , then $H_{0}$ was rejected and $H_{a}$ was accepted. Then, the result of the classical completeness test obtained in the experimental class 1 were $80 \%$ and experimental class 2 were $80.95 \%$. Based on the results of data analysis it can be concluded that the problem-solving learning model is effective against students' learning outcomes in the acid-base solutions topic in SMA Negeri 1 Buko on Academic Year 2018-2019.
\end{abstract}

Keywords: Effectiveness, problem solving, learning outcomes, acid-base material

\section{Pendahuluan}

Mata pelajaran kimia merupakan mata pelajaran wajib bagi siswa SMA, khususnya jurusan IPA dan merupakan salah satu mata pelajaran yang erat kaitannya dengan lingkungan (Supardi \& Putri, 2010). Ilmu kimia, juga mempelajari gejala-gejala alam, tetapi mengkhususkan diri di dalam mempelajari struktur, susunan, sifat dan perubahan materi, serta energi yang menyertai perubahan materi (Argandi dkk., 2013). Pembelajaran kimia di SMA perlu ditingkatkan dalam pemahaman siswa terhadap pemanfaatan dan penerapannya di masyarakat. Mata pelajaran ini perlu diajarkan untuk tujuan yang lebih khusus yaitu membekali peserta didik pengetahuan, pemahaman dan sejumlah kemampuan yang dipersyaratkan untuk memasuki jenjang pendidikan yang lebih tinggi serta mengembangkan ilmu dan teknologi (Fajri dkk., 2012).

Bagi sebagian besar mahasiswa, ilmu kimia merupakan salah satu materi yang sulit
(Mustapa, 2014). Indikasi bahwa pembelajaran mengalami kesulitan dalam memahami konsep kimia diperlihakan oleh beberapa fakta berikut. Hasil analisis UN tahun 2008 s.d 2010 di Sulawesi Tengah Kabupaten Donggala pencapaian ketuntasan kelulusan minimal (KKM) untuk materi tertentu seperti laju reaksi (57.25\%), termokimia (34.13\%), kesetimbangan kimia (35.99\%), pH larutan (46.9\%) dan ikatan kimia (28.91\%) masih jauh di bawah standar kompetensi kelulusan (SKL) $\geq 60 \%$. Gejala-gejala yang serupa terjadi pada mahasiswa kimia FKIP Universitas Tadulako. Hasil evaluasi perkuliahan Kimia Dasar tahun 2009/2010 dilaporkan kelulusan mahasiswa hanya mencapai $62 \%$ di bawah SKL (70\%) (Santoso \& Supriadi, 2014).

Berdasarkan hasil observasi di SMA Negeri 1 Buko, penulis menemukan bahwa dalam proses pembelajaran, sebagian besar guru mengajarkan materi kimia dengan menggunakan metode konvensional dan hanya kadang-kadang mengajar dengan menggunakan metode diskusi. Presentasi siswa hanya sesekali saja dilakukan

${ }^{*}$ Correspondence:

Yulianti Siako

e-mail: yulianti97siako@gmail.com

(c) 2020 the Author(s) retain the copyright of this article. This article is published under the terms of the Creative Commons Attribution License 4.0, which permits unrestricted non-commercial use, distribution, and reproduction in any medium, provided the original work is properly cited. 
dan tidak pernah terlaksananya kegiatan praktikum karena fasilitas laboratorium yang tersedia sudah lama rusak. Guru hanya menilai siswa memahami konsep kimia dan dari hasil ujian tertulis, sehingga rata-rata hasil belajar siswa cukup rendah. Sikap ilmiah siswa yang rendah berdampak pada hasil belajar yang diperoleh siswa (Supiawati dkk., 2018). Permasalahan dari siswa terletak pada kecenderungan siswa yang pasif dalam kegiatan pembelajaran, sedangkan permasalahan dari guru diantaranya masih menggunakan pembelajaran yang bersifat verbalistik (Yuniyanti dkk., 2012). Keberhasilan pencapaian kompetensi satu mata pelajaran bergantung kepada beberapa aspek. Salah satu aspek yang sangat mempengaruhi adalah bagaimana seorang guru dalam melaksanakan pembelajaran (Syazali, 2015).

Pemilihan model pembelajaran sangat penting dalam kegiatan belajar mengajar. Dengan pemilihan model pembelajaran yang sesuai, maka pemahaman konsep peserta didik dapat berkembang (Munira dkk., 2018). Peneliti dalam hal ini menerapkan model pembelajaran problem solving pada materi larutan asam basa. Asam basa merupakan salah satu materi kimia yang membutuhkan hafalan dan pemahaman, materi ini merupakan materi yang sarat dengan konsep dan berkaitan satu sama lain untuk mendukung materi selanjutnya yaitu hidrolisis, buffer, dan Ksp, sehingga perlu penanaman konsep yang utuh dan benar (Amalia \& Susilaningsih, 2014).

Problem solving merupakan salah satu model pembelajaran yang dapat meningkatkan keterampilan peserta didik seperti kemampuan bertanya, dan menjawab permasalahan, sehingga peserta didik terlibat aktif berpikir, berkomunikasi, mencari dan menyimpulkannya (Hidjrawan dkk., 2016). Model ini melatih siswa dalam menemukan konsep kimia sendiri dengan berlatih memecahkan masalah-masalah yang dihadapai dalam proses pembelajaran (Raehanah dkk., 2014). Pembelajaran model problem solving adalah suatu penyajian materi pelajaran dengan menghadapkan siswa kepada persoalan yang harus dipecahkan atau diselesaikan untuk mencapai tujuan pembelajaran (Ristiasari dkk., 2012). Karena dengan pemecahan masalah, siswa dimungkinkan untuk memperoleh pengalaman menggunakan pengetahuan serta keterampilan yang dimiliki untuk diterapkan pada pemecahan masalah yang bersifat tidak rutin (Yuwono, 2016).
Guru harus dapat memberikan cara pemecahan masalah yang semudah dan semenarik mungkin agar siswa memahami masalah yang diberikan dan mampu menemukan pemecahan yang terbaik dari setiap permasalahan (Purnomo \& Mawarsari, 2014). Oleh karena itu, tugas guru tidak hanya untuk mengajar siswa, tetapi membantu siswa belajar untuk menguasai konsep dan memecahkan masalah dengan berpikir kritis, logis, sistematis, dan terstruktur sehingga hasil pembelajaran siswa bisa memuaskan (Lamisu, 2014).

Melalui model pembelajaran problem solving tersebut siswa dilatih untuk memecahkan masalah dengan baik secara berkelompok. Adanya pembagian kelompok siswa dalam pembelajaran akan mendorong terjalinnya hubungan yang saling mendukung antar anggota kelompok. Siswa yang mengalami kesulitan dapat bertanya kepada teman dalam satu kelompoknya, sehingga diharapkan akan dapat meningkatkan kemampuan pemecahan masalah siswa dan hasil belajar yang diperoleh lebih maksimal (Totiana dkk., 2012).

Siswa memiliki dorongan semangat setelah proses pemecahan masalah karena pemecahan masalah berkontribusi pada penggunaan berbagai solusi dan pengembangan strategi yang digunakan siswa (Ersoy, 2014). Harapan dari penerapan model pembelajaran problem solving efektif dalam meningkatkan hasil belajar siswa pada materi larutan asam basa baik itu hasil belajar kognitif, afektif, maupun psikomotor.

Tulisan ini dimaksudkan untuk mendeskripsikan tentang efektivitas model pembelajaran problem solving terhadap hasil belajar siswa pada materi larutan asam basa di SMA Negeri 1 Buko tahun ajaran 2018-2019.

\section{Metode}

Penelitian ini menggunakan desain eksperimen murni (true eksperiment). Agar pelaksanaan model pembelajaran lebih efektif, maka dapat melalui metode eksperimen (Cheong, 2008). Kelas yang digunakan sebagai sampel adalah kelas eksperimen 1 dan kelas eksperimen 2, dimana keduanya merupakan kelas replikasi. Desain penelitian yang digunakan dalam penelitian adalah non-randomized posttest two group design yaitu dengan melihat hasil posttest pada kelas eksperimen 1 dan kelas eksperimen 2.

Tabel 1. Posttest two group design

\begin{tabular}{ccc}
\hline Kelas & Perlakuan & Posttest \\
\hline Eksperimen 1 & $\mathrm{X}_{1}$ & $\mathrm{~T}$ \\
Eksperimen 2 & $\mathrm{X}_{2}$ & $\mathrm{~T}$ \\
\hline
\end{tabular}


Dimana $\mathrm{T}$ adalah tes akhir (posttest) kelas eksperimen 1 dan eksperimen 2; $\mathrm{X}_{1}$ adalah model pembelajaran problem solving.

Penelitian ini dilaksanakan di SMA

Negeri 1 Buko. Populasi pada penelitian adalah siswa siswi kelas XI MIA yang terdaftar pada tahun ajaran 2018-2019 sebanyak 41 siswa. yang seluruhnya dijadikan sebagai sampel, yaitu kelas XI MIA 1 yang berjumlah 20 orang (7 laki-laki dan 13 perempuan) dan kelas eksperimen 2 merupakan kelas XI MIA 2 yang berjumlah 21 orang (7 laki-laki dan 14 perempuan). Pengambilan sampel dengan menggunakan teknik sampling jenuh.

Instrumen yang digunakan pada penelitian ini adalah RPP, LKPD, lembar observasi aktivitas guru dan siswa, lembar observasi keterlaksanaan pembelajaran, dan tes akhir pembelajaran (posttest) sebanyak 25 soal berbentuk pilihan ganda. Intrumen yang digunakan telah di validasi oleh validator ahli yang memiliki kemampuan di bidangnya. Penelitian ini dilaksanakan dengan tiga tahap yaitu tahap persiapan, tahap pelaksanaan, dan tahap akhir. Adapun tahap-tahap tersebut sebagai berikut:

\section{Tahap Persiapan}

Mencari referensi mengenai penelitian yang dilakukan, observasi lokasi, mewawancarai salah satu guru kimia yang ada di SMA Negeri 1 Buko, membuat rencana pelaksanaan pembelajaran (RPP), lembar kegiatan peserta didik (LKPD), lembar penilaian afektif dan psikomotor, lembar observasi aktivitas siswa dan guru, lembar observasi keterlaksanaan pembelajaran, dan mempersiapkan soal (posttest) untuk mengevaluasi hasil belajar siswa.

\section{Tahap Pelaksanaan}

Kegiatan yang dilakukan pada tahap ini adalah melakukan kegiatan belajar mengajar pada kedua kelas eksperimen dengan menerapkan model pembelajaran problem solving sebanyak tiga kali pertemuan pada setiap kelas.

\section{Tahap Akhir}

Kegiatan yang dilakukan pada tahap ini adalah menganalisis data dan menyusun hasil penelitian. Teknik analisis data yang digunakan pada penelitian ini yaitu analisisi statistik deskriptif dan statistik inferensial. Analisis statistik deskriptif yang digunakan yaitu rata-rata (mean) pencapaian skor pada penilaian afektif dan psikomotorik. Sedangkan analisis statistik inferensial yang digunakan adalah uji prasyarat (uji normalitas, uji homogenitas), dan uji hipotesis yaitu menggunakan uji-t dan uji ketuntasan klasikal (Riduwan, 2012).

\section{Hasil dan Pembahasan}

Hasil penelitian ini mencakup hasil yang di peroleh selama proses kegiatan belajar mengajar di kelas XI MIA 1 dan kelas XI MIA 2 dengan menggunakan model pembelajaran problem solving di SMA Negeri 1 Buko, dengan tujuan untuk melihat tingkat efektivitas model pembelajaran problem solving terhadap hasil belajar siswa.

\section{Analisis Data Posttest Hasil Belajar Siswa (Hasil Belajar Kognitif) \\ Data posttest siswa kelas eksperimen 1 dan kelas eksperimen 2 disajikan pada Tabel 2.}

Tabel 2. Data posttest hasil belajar siswa

\begin{tabular}{ccc}
\hline Uraian & \multicolumn{2}{c}{ Tes Akhir (Posttest) } \\
\cline { 2 - 3 } & Kelas Experimen 1 $\left(\mathrm{X}_{1}\right)$ & Kelas Eksperimen 2 $\left(\mathrm{X}_{2}\right)$ \\
\hline Sampel & 20 & 21 \\
Nilai Terendah & 40 & 56 \\
Nilai Tertinggi & 88 & 92 \\
Banyaknya siswa yang belum tuntas & 3 orang & 4 orang \\
Nilai Rata-rata Kelas & 75.5 & 76.43 \\
Ketuntasan klasikal & $85 \%$ & $80.95 \%$ \\
Standar Deviasi & 10.712 & 12.773 \\
\hline
\end{tabular}

\section{Uji Normalitas}

Uji normalitas digunakan sebagai syarat atau asumsi dari berbagai uji parametrik. Data yang duji normalitasnya adalah keseluruhan data posttest hasil belajar kedua kelas yang digunakan sebagai sampel. Uji normalitas pada penelitian ini menggunakan metode one sample Kolmogorof Smirnov test dengan menggunakan aplikasi statistik. Interpretasinya dengan melihat hasil output pada bagian Asymp. Sig (2-tailed). Apabila nilai signifikansi lebih besar dari 0.05 , maka data tersebut dinyatakan berdistribusi normal. Hasil uji normalitas data kelas eksperimen 1 diperoleh nilai Asymp. Sig (2-tailed) sebesar 0.061, sedangkan untuk kelas eksperimen 2 diperoleh nilai Asymp. Sig (2-tailed) sebesar 0.081). Hasil tersebut menunjukan bahwa kedua kelas eksperimen memiliki data yang berdistribusi normal.

\section{Uji Homogenitas}

Uji homogenitas digunakan untuk menguji apakah data posttest hasil belajar yang diperoleh pada kelas eksperimen 1 dan kelas eksperimen dua tersebut homogen yaitu dengan cara membandingkan kedua variansnya. 
Pengujian homogenitas juga dilakukan menggunakan aplikasi statistik. Nilai signifikansi (Sig) yang diperoleh adalah 0.890. Karena nilai signifikansi $>0.05$ maka dapat disimpulkan bahwa data tersebut homogen sehingga dianggap memenuhi syarat untuk uji parametrik dalam hal ini uji $t$.

\section{Uji Hipotesis}

Uji hipotesis digunakan untuk membuktikan kebenaran dari hipotesis yang digunakan yaitu model pembelajaran problem solving efektif terhadap hasil belajar siswa. Tingkat efektivitas dianalisis dari data posttest hasil belajar siswa dengan menggunakan uji ketuntasan hasil belajar individu dan uji ketuntasan klasikal.

Uji ketuntasan hasil belajar individu digunakan untuk mengetahui rata-rata data akhir pada sampel mencapai ketuntasan individual atau tidak. Uji ketuntasan hasil belajar individu diuji dengan uji parametrik yaitu menggunakan rumus statistika t (uji t) satu sampel (one sample t-test method) yang merupakan prosedur uji t untuk sampel tunggal jika rata-rata suatu variabel tunggal dibandingkan dengan suatu nilai konstanta tertentu. Uji t ini dipakai jika jumlah data sampel dibawah 30 dengan syarat bahwa data tersebut merupakan data kuantitatif dan memenuhi asumsi berdistribusi normal. Uji ketuntasan hasil belajar individu dikatakan mencapai ketuntasan individual jika nilai $t_{\text {hitung }}>$ $t_{\text {tabel. }}$.

$$
\begin{aligned}
& \text { Uji Ketuntasan belajar individu }(\mathrm{t})_{\text {hitung }}=\frac{\bar{x}-\mu 0}{\mathrm{~S} / \sqrt{\mathrm{n}}} \\
& \text { Keterangan: } \mathrm{t}=\text { Tingkat keefektifan } \\
& \bar{x}=\text { Rata-rata hasil belajar siswa } \\
& \mathrm{S}=\text { Simpangan baku } \\
& \mathrm{n}=\text { Banyak siswa }
\end{aligned}
$$

$2.321>2.101$ dengan taraf kepercayaan 0.05 dan derajat kebebasan $=18$, sedangkan pada kelas eksperimen 1 diperoleh nilai $\mathrm{t}_{\text {hitung }}>\mathrm{t}_{\text {tabel }}$ yaitu $2.306>2.093$ dengan taraf kepercayaan 0.05 dan derajat kebebasan $=19$. Adapun arti $\alpha=0.05$ ialah kira-kira 0.05 dari 100 kesimpulan akan menolak hipotesis yang seharusnya diterima atau dengan kata lain kira-kira 95\% percaya bahwa kita telah membuat kesimpulan yang benar.

Uji ketuntasan klasikal digunakan untuk mengetahui persentase ketuntasan belajar dari kelas yang digunakan sebagai sampel. Uji ketuntasan klasikal dihitung dengan menggunakan rumus sebagai berikut.

$$
\begin{aligned}
& \text { Ketuntasan klasikal }(\%)=\frac{\mathrm{x}}{\mathrm{n}} \times 100 \% \\
& \text { Keterangan: } \\
& \qquad \begin{aligned}
\mathrm{n}= & \text { jumlah seluruh siswa } \\
\mathrm{x} & =\begin{array}{l}
\text { jumlah siswa yang mencapai } \\
\text { ketuntasan belajar }
\end{array}
\end{aligned}
\end{aligned}
$$

Berdasarkan rumus yang digunakan, hasil uji ketuntasan klasikal yang diperoleh pada kelas eksperimen 1 adalah sebesar $85 \%$ dan pada kelas eksperimen 2 sebesar $80.95 \%$. Suatu pembelajaran dikatakan efektif jika nilai rata-rata hasil belajar siswa berada pada rentang antara 75 - 87 dengan ketuntasan hasil belajar siswa 75\% 87\% (Mulyasa, 2004).

\section{Hasil Belajar Afektif}

Ranah afektif yang digunakan untuk menilai siswa berjumlah 5 aspek. Tiap aspek dianalisis sacara deskriptif yang bertujuan untuk mengetahui aspek mana yang dimiliki siswa untuk dibina dan dikembangkan. Nilai afektif kelas eksperimen 1 dan kelas eksperimen 2 dapat dilihat pada Tabel 3.

Tabel 3. Analisis hasil belajar afektif

\begin{tabular}{ccccc}
\hline \multirow{2}{*}{ Aspek } & \multicolumn{2}{c}{ Eksperimen 1 } & \multicolumn{2}{c}{ Eksperimen 2 } \\
\cline { 2 - 5 } & Rata-rata & Kategori & Rata-rata & Kategori \\
\hline Kehadiran Siswa dalam proses & 3.90 & Sangat Baik & 3.80 & Sangat Baik \\
pembelajaran & 3.45 & Sangat Baik & 3.47 & Sangat Baik \\
Rasa ingin tahu & 3.90 & Sangat Baik & 3.90 & Sangat Baik \\
Jujur & 3.35 & Sangat Baik & 3.47 & Sangat Baik \\
Disiplin dan Bertanggung jawab & 4 & Sangat Baik & 3.8 & Sangat Baik \\
Menghargai pendapat orang lain & & & &
\end{tabular}

Dari hasil belajar afektif yang diperoleh, dapat diketahui bahwa hasil belajar afektif kelas eksperimen 1 dan kelas eksperimen 2 masuk dalam kategori sangat baik.

\section{Hasil Belajar Psikomotor}

Ranah psikomotorik yang digunakan untuk menilai ada 7 aspek. Aspek ini dinilai pada saat pelaksanaan praktikum larutan asam basa Berdasarkan hasil observasi yang dilakukan selama pembelajaran, diperoleh hasil analisis skor aspek psikomotorik pada tiap-tiap aspek. Nilai psikomotorik kelas eksperimen 1 dan kelas eksperimen 2 dapat dilihat pada Tabel 4.

Berdasarkan keseluruhan data yang diperoleh, dapat dinyatakan bahwa model pembelajaran problem solving efektif terhadap hasil belajar. Hal ini disebabkan karena pada proses pembelajaran dengan menggunakan model problem solving melibatkan siswa untuk aktif dalam memecahkan masalah. 
Tabel 4. Analisis hasil belajar psikomotor

\begin{tabular}{ccccc}
\hline Aspek & \multicolumn{2}{c}{ Kelas Eksperimen 1 } & \multicolumn{2}{c}{ Kelas Eksperimen 2 } \\
\cline { 2 - 5 } & $\begin{array}{c}\text { Rata- } \\
\text { rata }\end{array}$ & Kategori & Rata-rata & Kategori \\
\hline $\begin{array}{c}\text { Persiapan alat dan bahan } \\
\text { Penguasaan prosedur } \\
\text { praktikum }\end{array}$ & 3.30 & Sangat Baik & 3.33 & Sangat Baik \\
$\begin{array}{c}\text { Ketepatan dalam } \\
\text { melakukan pengamatan } \\
\text { Kerjasama dalam }\end{array}$ & 2.75 & Baik & 3.00 & Baik \\
$\begin{array}{c}\text { kelompok } \\
\text { Kemampuan }\end{array}$ & 3.60 & Sangat Baik & 3.09 & Baik \\
$\begin{array}{c}\text { berkomunikasi } \\
\text { Menarik simpulan hasil } \\
\text { percobaan }\end{array}$ & 2.90 & Sangat Baik & 3.76 & Sangat Baik \\
$\begin{array}{c}\text { Kemampuan membuat } \\
\text { laporan praktikum }\end{array}$ & 3.60 & Baik & 3.00 & Baik \\
\hline
\end{tabular}

Model pembelajaran problem solving mempunyai beberapa kelebihan diantaranya: (1) Pembelajaran ini dapat membuat pendidikan di sekolah menjadi lebih relevan dengan kehidupan; (2) Proses belajar mengajar melalui pemecahan masalah dapat membiasakan para siswa menghadapi dan memecahkan masalah secara terampil; (3) Pembelajaran ini merangsang pengembangan kemampuan berpikir siswa secara kreatif dan menyeluruh, karena dalam proses belajarnya, siswa banyak melakukan mental dengan menyoroti permasalahan dari berbagai segi dalam rangka mencari pemecahannya (Djamarah \& Zain, 2002).

\section{Kesimpulan}

Model pembelajaran problem solving efektif terhadap hasil belajar siswa Hal ini dapat dilihat dari hasil belajar yang diperoleh siswa dimana nilai rata-rata kedua kelas eksperimen adalah 75.96. Hasil belajar kognitif yang diperoleh dari hasil uji ketuntasan belajar individu pada kelas eksperimen 1, diperoleh nilai $\mathrm{t}_{\text {hitung }}>\mathrm{t}_{\text {tabel }}$ yaitu $2.321>2.101$ dan pada kelas eksperimen 2, nilai $t_{\text {hitung }}>t_{\text {tabel }}$ yaitu 2.306 $>2.093$, dan juga hasil uji ketuntasan klasikal dimana ketuntasan klasikal pada kelas eksperimen 1 sebesar $85 \%$ dan kelas eksperimen 2 sebesar $80.95 \%$. Hasil belajar aspek afektif kelas eksperimen 1 dan kelas eksperimen 2 memiliki nilai rata-rata yang sama yaitu 3.72 atau masuk dalam kategori sangat baik, sedangkan hasil belajar aspek psikomotorik pada kelas eksperimen 1 diperoleh nilai rata-rata 3.19 , sedangkan pada kelas ekspeimen 2 diperoleh nilai rata-rata 3.28 dimana kedua nilai tersebut masuk dalam kategori sangat baik.

\section{Ucapan Terima Kasih}

Penulis mengucapkan terima kasih kepada, I Wayan Suasta, kepala SMA Negeri 1 Buko, Yamerti Yuasi dan Boni Alep, guru mata pelajaran kimia dan seluruh siswa kelas XI MIA sebagai sampel dalam penelitian tahun ajaran 2018/2019, serta semua pihak yang banyak membantu penulis dalam menyelesaikan penelitian ini.

\section{Referensi}

Amalia, N. F., \& Susilaningsih, E. (2014). Pengembangan instrumen penilaian keterampilan berpikir kritis siswa SMA pada materi asam basa. Jurnal Inovasi Pendidikan Kimia, 8(2), 1380-1389.

Argandi, R., Martini, K. S., \& Saputro, A. N. C. (2013). Pembelajaran kimia dengan metode inquiri terbimbing dilengkapi kegiatan laboratorium real dan virtual pada pokok bahasan pemisahan campuran. Jurnal Pendidikan Kimia, 2(2), 44-49.

Cheong, F. (2008). Using a problem-based learning approach to teach an intelligent systems course. Journal of Information Technology Education, 7(20), 47-59.

Djamarah, S. B., \& Zain, A. (2002). Strategi belajar mengajar. Jakarta: Rineka cipta.

Ersoy, E. (2014). Problem solving and its teaching in mathematics. The Online Journal of New Horizons in Education, 6(2), 79-87.

Fajri, L., Martini, K. S., \& Nugroho, A. (2012). Upaya peningkatan proses dan hasil belajar kimia materi koloid melalui pembelajaran kooperatif tipe tgt (teams games tournament) dilengkapi dengan teka-teki silang bagi siswa kelas XI IPA 4 SMA Negeri 2 Boyolali pada semester genap tahun ajaran 2011/2012. Jurnal Pendidikan Kimia, 1(1), 89-96.

Hidjrawan, Y., Khaldun, I., \& Sari, S. A. (2016). Efektivitas model pembelajaran problem solving terhadap keterampilan berpikir kritis dan hasil belajar peserta didik pada materi larutan penyangga di SMAN 7 Banda Aceh. Jurnal Pendidikan Sains Indonesia, 4(2), 140150.

Lamisu. (2014). Mathematical problem solving of students by approach behavior learning theory. International Journal of Education and Research, 2(10), 181-188. 
Mulyasa, E. (2004). Kurikulum berbasis kompotensi. Bandung: Remaja rosdakarya.

Munira, J., Yusrizal, \& Safitri, R. (2018). Efektivitas model pembelajaran problem solving untuk meningkatkan pemahaman konsep peserta didik di SMA Negeri 11 Banda Aceh. Jurnal Pendidikan Sains Indonesia, 6(1), 40-45.

Mustapa, K. (2014). Pengaruh strategi pembelajaran terhadap kemampuan berpikir tingkat tinggi. Jurnal Pendidikan Humaniora, 2(4), 348-357.

Purnomo, E. A., \& Mawarsari, V. D. (2014). Peningkatan kemampuan pemecahan masalah melalui model pembelajaran ideal problem solving berbasis project based learning. Jurnal Kajian Pendidikan Matematika, 1(1), 24-31.

Raehanah, Mulyani, S., \& Saputro, S. (2014). Pembelajaran kimia menggunakan model problem solving tipe search, solve, create and share (SSCS) dan cooperative problem solving (CPS) ditinjau dari kemampuan berpikir kritis dan kemampuan matematis. Inkuiri: Jurnal Pendidikan IPA, 3(1), 19-27.

Riduwan. (2012). Dasar-dasar statistika. Bandung: Alfabeta.

Ristiasari, T., Priyono, B., \& Sukaesih, S. (2012). Model pembelajaran problem solving dengan mind mapping terhadap kemampuan berpikir kritis siswa. Unnes Journal of Biology Education, 1(3), 35-41.

Santoso, T., \& Supriadi. (2014). Pembelajaran penalaran argumen berbasis peta konsep untuk meningkatkan pemahaman konsep kimia. Prosiding Seminar Nasional Kimia, 134-143. Surabaya.
Supardi, I. K., \& Putri, I. R. (2010). Pengaruh penggunaan artikel kimia dari internet pada model pembelajaran creative problem solving terhadap hasil belajar kimia siswa SMA. Jurnal Inovasi Pendidikan Kimia, 4(1), 574581.

Supiawati, Kurniawan, R. A., \& Kurniati, T. (2018). Pengaruh praktikum berbasis inkuiri terbimbing terhadap sikap ilmiah dan hasil belajar siswa pada materi hidrolisis garam. Pena Kreatif: Jurnal Pendidikan, 7(1), 34-35.

Syazali, M. (2015). Pengaruh model pembelajaran creative problem solving berbantuan mapple II terhadap kemampuan pemecahan masalah matematis. Jurnal Pendidikan Matematika, 6(1), 91-98.

Totiana, F., Susanti, E., \& Redjeki, T. (2012). Efektivitas model pembelajaran creative problem solving (CPS) yang dilengkapi media pembelajaran laboratorium virtual terhadap prestasi belajar siswa pada materi koloid kelas XI IPA semester genap SMA Negeri 1 Karanganyar tahun pelajaran 2011/2012. Jurnal Pendidikan Kimia, 1(1), 74-79.

Yuniyanti, D. E., Sunarno, W., \& Haryono. (2012). Pembelajaran kimia menggunakan inkuiri terbimbing dengan media modul dan e-learning ditinjau dari kemampuan pemahaman membaca dan kemampuan berpikir abstrak. Jurnal Inkuiri, 1(2), 112 120.

Yuwono, A. (2016). Problem solving dalam pembelajaran matematika. Jurnal Pendidikan Matematika, 4(1), 143-156. 